\title{
Epidemiology and genetic diversity of Taenia asiatica: a systematic review
}

\author{
Anita Ale ${ }^{1}$, Bjorn Victor ${ }^{2}$, Nicolas Praet $^{2}$, Sarah Gabriël ${ }^{2}$, Niko Speybroeck ${ }^{3}$, Pierre Dorny ${ }^{2,4}$ \\ and Brecht Devleesschauwer ${ }^{3,4^{*}}$
}

\begin{abstract}
Taenia asiatica has made a remarkable journey through the scientific literature of the past 50 years, starting with the paradoxical observation of high prevalences of $T$. saginata-like tapeworms in non-beef consuming populations, to the full description of its mitochondrial genome. Experimental studies conducted in the 1980s and 1990s have made it clear that the life cycle of $T$. asiatica is comparable to that of $T$. saginata, except for pigs being the preferential intermediate host and liver the preferential location of the cysts. Whether or not T. asiatica can cause human cysticercosis, as is the case for Taenia solium, remains unclear. Given the specific conditions needed to complete its life cycle, in particular the consumption of raw or poorly cooked pig liver, the transmission of T. asiatica shows an important ethno-geographical association. So far, T. asiatica has been identified in Taiwan, South Korea,

Indonesia, the Philippines, Thailand, south-central China, Vietnam, Japan and Nepal. Especially this last observation indicates that its distribution is not restricted to South-East-Asia, as was thought so far. Indeed, the molecular tools developed over the last 20 years have made it increasingly possible to differentiate T. asiatica from other taeniids. Such tools also indicated that T. asiatica is related more closely to T. saginata than to T. solium, feeding the debate on its taxonomic status as a separate species versus a subspecies of $T$. saginata. Furthermore, the genetic diversity within T. asiatica appears to be very minimal, indicating that this parasite may be on the verge of extinction. However, recent studies have identified potential hybrids between T. asiatica and T. saginata, reopening the debate on the genetic diversity of $T$. asiatica and its status as a separate species.
\end{abstract}

Keywords: Transmission, Geographical distribution, Genetic diversity, Taenia asiatica

\section{Background: the journey of a new tapeworm}

The journey of Taenia asiatica, as documented by scientific literature, started in Taiwan in the late 1960s. Several authors reported on the paradox of observing a high prevalence of Taenia saginata-like tapeworms in the native aboriginal population living in mountainous areas of Taiwan, while these populations restrained from beef consumption (reviewed by $[1,2]$ ), and meat inspection for bovine cysticercosis had been negative for some time [3]. Dr Ping-Chin Fan, a Taiwanese parasitologist, conducted various studies on this Taiwan Taenia in the late 1980s and early 1990s (reviewed by [1,4-6]).

\footnotetext{
* Correspondence: brecht.devleesschauwer@ugent.be

${ }^{3}$ Institute of Health and Society (IRSS), Université catholique de Louvain,

Brussels, Belgium

${ }^{4}$ Department of Virology, Parasitology and Immunology, Faculty of Veterinary Medicine, Ghent University, Merelbeke, Belgium

Full list of author information is available at the end of the article
}

Through observational and experimental studies, he and his team observed the morphology and researched the epidemiology of the Taiwan Taenia, which diverged from that of T. saginata. This led Fan to raise the possibility of the Taiwan Taenia being a new species [4].

Further experimental studies on $T$. saginata-like tapeworms from South Korea, Indonesia, Thailand, and the Philippines showed similar results, leading the authors to rename their Taiwan Taenia into Asian Taenia, denoting its more diverse geographical distribution [7-10].

In the early 1990s, a group of Korean parasitologists, led by Dr Keeseon Eom, performed various experimental infections using Korean specimens of the Asian Taenia. Their observation that the cysts of the Asian Taenia preferably develop in viscera of pigs, made them propose the name Cysticercus viscerotropica [11]. In 1993, they described the morphology of the Asian Taenia, and declared it as a new species, designated Taenia asiatica [12]. 
With the advent of molecular techniques, it became clear that the Asian Taenia is genetically much more related to T. saginata than it is to T. solium [13-17]. This led the earlier protagonists to declare the Asian Taenia as a strain or subspecies of $T$. saginata, designated Taenia saginata taiwanensis, or, in line with its geographical distribution, Taenia saginata asiatica [18].

However, this purely molecular view was soon contrasted to an epidemiological and public health perspective. Galan-Puchades and Mas-Coma opened the debate, and made the case for $T$. asiatica as a separate species [19]. The debate continued, with different phylogenetic studies considering the Asian Taenia either as T. saginata asiatica [20,21] or T. asiatica [22-27], depending on the research group involved. The identification of $T$. saginatal T. asiatica hybrids in China and Thailand [28-30], may reopen this debate, as reproductive isolation has historically been an important criterion for considering $T$. asiatica and $T$. saginata as distinct biological entities [24]. Although the current literature seems to favor T. asiatica at the species level, it is clear that the taxonomy of the Asian Taenia remains as complex and controversial as it was two decades ago [31].

The remainder of this systematic review will provide an update of our current understanding of the transmission, risk factors, geographical distribution and genetic diversity of $T$. asiatica. For a review on the history, taxonomy and morphology of T. asiatica, we refer to Eom [32].

\section{Search strategy}

Evidence on the epidemiology and genetic diversity of $T$. asiatica was obtained through a systematic search of national and international peer-reviewed literature. Given the relatively limited number of papers on $T$. asiatica, a general search phrase was used consisting of the different synonyms of $T$. asiatica, i.e., Taenia saginata asiatica, Asian Taenia and Taiwan Taenia. Manuscript titles were retrieved through searching PubMed, Asia Journals OnLine (AsiaJOL), African Journals OnLine (AJOL), Latin American Journals OnLine (LAMJOL), WHO Global Health Library, and IndMED. The searches were performed on 20 September 2013.

In a second step, the retrieved titles were screened for eligibility by applying a set of inclusion/exclusion criteria to the titles and, if possible, to the abstracts and full texts. Papers were included if they provided authentic information on the transmission, geographic distribution and/or genetic diversity of $T$. asiatica. No restrictions were imposed on the publication year or on the language of the manuscript. Non-English manuscripts were translated through Google Translate (http://translate.google.be/).

In a third step, additional titles were retrieved by hand-searching the reference lists of the eligible documents initially retrieved. The same inclusion/exclusion criteria as for the initial titles were applied to these new titles. The backward reference searches were repeated until no more new information could be retrieved.

In a fourth and final step, a narrative synthesis of each paper was made, serving as the basis for the current qualitative review of the epidemiology and genetic diversity of $T$. asiatica.

Figure 1 shows a flow diagram of the applied search strategy. In total, 162 relevant unique records could be identified, of which 15 had to be translated from Chinese $(\mathrm{n}=14)$ or Korean $(\mathrm{n}=1)$. Of the 162 unique records, 49 provided information on the transmission and risk factors of $T$. asiatica; 92 on its geographical distribution; and 42 on its genetic diversity. Several studies provided information on multiple aspects covered by this review.

\section{Review}

\section{Transmission and risk factors}

The transmission and infectivity potential of $T$. asiatica has been extensively studied in the 1980s and 1990s through experimental studies $[1,4,11,33]$. Humans act as definite host, while pigs appear to act as natural intermediate hosts. However, other animals, such as cattle, goats and certain monkey species were also found to become infected [1,8-11,34]. Experimental infections with the eggs of Asian Taenia in cats, dogs, rabbits, rodents and baboons (Papio hamadryas), on the other hand, were not successful $[1,35]$.

The life cycle of $T$. asiatica appears to be rather short compared to other human Taenia species. Approximately four weeks after ingestion of eggs, mature cysts become visible in the intermediate host $[1,11]$. T. asiatica cysts are mainly found in the liver of intermediate hosts, and more so in the parenchyma than on the surface. Other viscera, such as lungs, omentum, serosa and mesentery, may also harbor cysts $[11,34,36]$. These extrahepatic cysts are believed to have migrated from the liver surface [34]. Two to four months after ingestion of viable cysts by a human host, motile tapeworm segments may be excreted with the stool $[33,37,38]$. The number of proglottids released per day may vary from 0 to 35 [37,38]. Cases have been reported of carriers passing proglottids for more than 30 years $[39,40]$, although it cannot be ascertained if this was due to the same tapeworm or due to reinfection.

Comparatively, the life cycle of $T$. asiatica closely follows that of $T$. saginata, with the exception of the natural intermediate host (pigs versus cattle), and the location in the intermediate host (liver versus muscle). A matter of debate remains whether $T$. asiatica may also infect humans as intermediate host, as is the case for the other human taeniid, T. solium. Experimental infections with $T$. asiatica eggs in primates remain inconclusive, as Fall et al. [35] were not able to infect 


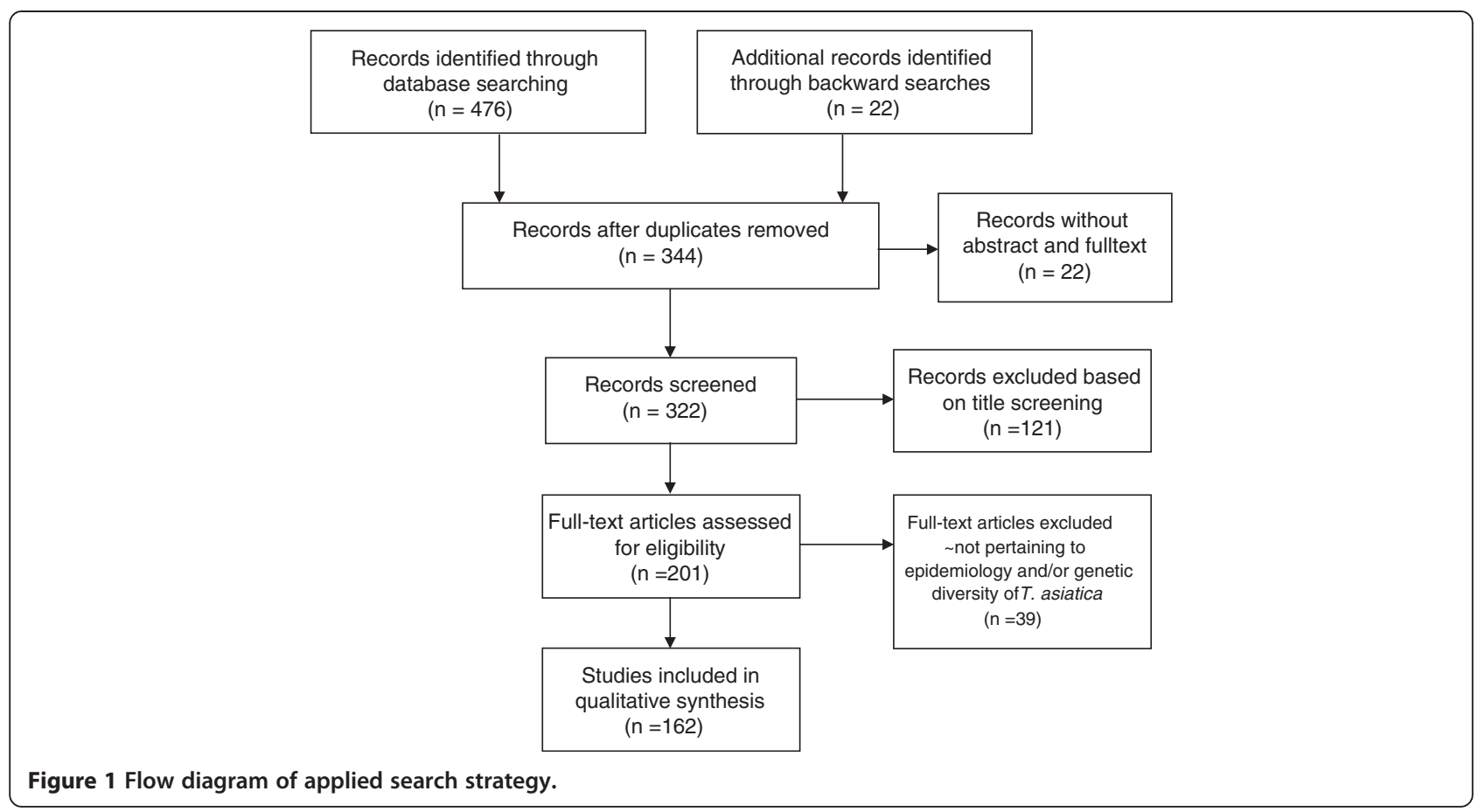

baboons, but other researchers did report successful infections in Macaca cyclopis and other unspecified monkey species [1,34]. Galan-Puchades \& Fuentes $[41,42]$ argue that, if $T$. asiatica were to cause cysticercosis, the location of the cysts would most likely be the liver, as in other intermediate hosts. Hepatic cysticercosis, if existing, would most probably not give rise to clinical symptoms, given the small size of the cysts. On the other hand, from a diagnostic point of view, cross-reactions in tests for the detection of other Taenia spp. would be very plausible, as cross-immunity and in vitro cross-reactions have been observed at various times [43-48].

The life cycle of $T$. asiatica indicates that the main transmission risk factors are raw pork viscera consumption (to infect the human host), and open defecation (to infect the intermediate host) [32]. As the consumption of (raw) pork viscera is generally less popular than that of (raw) pork meat, $T$. asiatica cannot efficiently spread within and between countries and acquire a true cosmopolitan status. However, social, cultural, and religious practices have preserved raw pork liver consumption in certain population groups, leading to high prevalences in these specific population groups, who often live in specific geographical areas. Indeed, observations from various countries demonstrate that transmission of $T$. asiatica is clearly ethnically and geographically associated. Table 1 gives an overview of the different ethno-geographical foci where $T$. asiatica has been studied. Remarkably, most of these foci were islands, which possibly facilitated the preservation of $T$. asiatica in these foci.
Earlier studies reported an increasing prevalence with age $[1,50,52]$, while others reported a predominance in males [62]. However, these findings can probably be attributed to differential consumption patterns.

\section{Geographical distribution}

The current state of knowledge on the geographical distribution of $T$. asiatica is visualized in Figure 2. Most knowledge originates from the analysis of individual specimens and limited case series. Observational studies on $T$. asiatica remain largely lacking, mainly due to the difficulty in identifying tapeworm carriers and the subsequent collection and identification of tapeworm specimens. As a result, the true prevalence of $T$. asiatica taeniosis remains unknown.

To date, most observations originate from the countries where $T$. asiatica was initially studied, i.e., Taiwan and South Korea. In fact, high taeniosis prevalences have been reported from these countries since the beginning of the 20th century, although it is unclear to what extent these cases were due to $T$. asiatica. The first report from Taiwan is ascribed to Oi (1915; cited by [2]), while the first report from South Korea is ascribed to Matsumoto (1915; cited by [55]). Zarlenga et al. [13] were the first to confirm $T$. asiatica specimens at the molecular level in these countries, and several studies would follow (e.g., [15,29,57,66-69]). Interestingly, Jeon et al. [70] found that 51 out of 68 museum specimens, preserved since 1935-2005 and originating from different South Korean provinces, were in fact $T$. asiatica, whereas they were 


\section{Table 1 Ethno-geographical foci of Taenia asiatica transmission}

\begin{tabular}{|c|c|c|c|c|}
\hline Country & Region & People & Food habits & References \\
\hline Taiwan & $\begin{array}{l}\text { Mountainous areas of northern and eastern } \\
\text { Taiwan }\end{array}$ & Bunun, Atayal & $\begin{array}{l}\text { Habit of eating viscera, especially liver and blood, } \\
\text { of fresh-killed animals, including wild boar, but excluding cattle }\end{array}$ & $\begin{array}{l}\text { Fan } 1988 \text { [1]; Chung et al. 1990 [39]; Fan et al. } \\
1990 \text { [49]; Fan et al. 1992a [40]; Ooi et al. } 2013 \text { [2] }\end{array}$ \\
\hline Taiwan & $\begin{array}{l}\text { Orchid island, Lanyu Township, Taitung } \\
\text { County, southeastern Taiwan }\end{array}$ & $\begin{array}{l}\text { Tao (originally } \\
\text { known as Yami) }\end{array}$ & $\begin{array}{l}\text { Habit of eating viscera, especially liver and blood, } \\
\text { of fresh-killed animals, including wild boar, but excluding cattle }\end{array}$ & $\begin{array}{l}\text { Fan et al. 1992b [50]; Eom et al. } 2009 \text { [51]; Ooi } \\
\text { et al. } 2013 \text { [2] }\end{array}$ \\
\hline Indonesia & $\begin{array}{l}\text { Ambarita village, Samosir Island, northern } \\
\text { Sumatra }\end{array}$ & Batak (Christian) & $\begin{array}{l}\text { "Sang-sang": traditional dish with minced pork, } \\
\text { viscera and blood; during preparation, uncooked meat and } \\
\text { viscera are sometimes eaten }\end{array}$ & $\begin{array}{l}\text { Fan et al. } 1989 \text { [7]; Fan et al. 1992c [52]; } \\
\text { Suroso et al. } 2006 \text { [53]; Wandra et al. } 2006 \text { [54] }\end{array}$ \\
\hline $\begin{array}{l}\text { South } \\
\text { Korea }\end{array}$ & $\begin{array}{l}\text { Jeju Island (Jeju-do) and mainland South } \\
\text { Korea }\end{array}$ & $\begin{array}{l}\text { Not minority people } \\
\text { as seen in other } \\
\text { countries }\end{array}$ & $\begin{array}{l}\text { Habit of eating liver and other viscera of pigs at "Churyum", } \\
\text { a common rural practice of slaughtering pigs at home during } \\
\text { weddings, funerals and other special occasions }\end{array}$ & $\begin{array}{l}\text { Fan et al. 1992b [50]; Eom et al. } 1992 \text { [11]; Eom \& } \\
\text { Rim } 2001 \text { [55]; Galan-Puchades \& Fuentes } 2001 \\
\text { [56] }\end{array}$ \\
\hline China & $\begin{array}{l}\text { Luzhai County, Guangxi Zhuang } \\
\text { Autonomous Region, southern China }\end{array}$ & Zhuang & $\begin{array}{l}\text { Habit of eating raw pork and pig liver, unseasoned or mixed with } \\
\text { sour sauce and salted garlic; consumption of raw beef is } \\
\text { uncommon }\end{array}$ & Eom et al. 2002 [57]; Eom et al. 2009 [51] \\
\hline China & $\begin{array}{l}\text { Yajiang (Nyagqu) County, Garzê Tibetan } \\
\text { Autonomous Prefecture, Sichuan Province }\end{array}$ & Kham Tibetans & Habit of eating raw pork and beef & Li et al. 2006 [58]; Li et al. 2013 [59] \\
\hline Thailand & $\begin{array}{l}\text { Thong Pha Phum District, Kanchanaburi } \\
\text { Province, west-central Thailand, Thai- } \\
\text { Myanmar border }\end{array}$ & Karen & $\begin{array}{l}\text { Habit of eating raw or under cooked beef, pork, or pig viscera and } \\
\text { fresh blood }\end{array}$ & $\begin{array}{l}\text { Anantaphruti et al. } 2007 \text { [60]; Anantaphruti et al. } \\
2010 \text { [61]; Anantaphruti 2013 [62] }\end{array}$ \\
\hline Japan & Kanto region, central Honshu & $\begin{array}{l}\text { Not minority people } \\
\text { as seen in other } \\
\text { countries }\end{array}$ & $\begin{array}{l}\text { Serving of pig liver "sashimi" (raw slices) at "yakitori" or "yakiniku" } \\
\text { restaurants }\end{array}$ & $\begin{array}{l}\text { Eom et al. } 2009 \text { [51]; Michelet \& Dauga } 2012 \text { [63]; } \\
\text { Yamasaki } 2013 \text { [64] }\end{array}$ \\
\hline Nepal & Morang \& Sunsari district, southeastern Nepal & Dum & $\begin{array}{l}\text { Frequent pork consumption; habit of eating undercooked meat } \\
\text { and viscera of home raised Hurra piglets during certain religious and } \\
\text { social festivities }\end{array}$ & Devleesschauwer et al. 2012 [65] \\
\hline
\end{tabular}




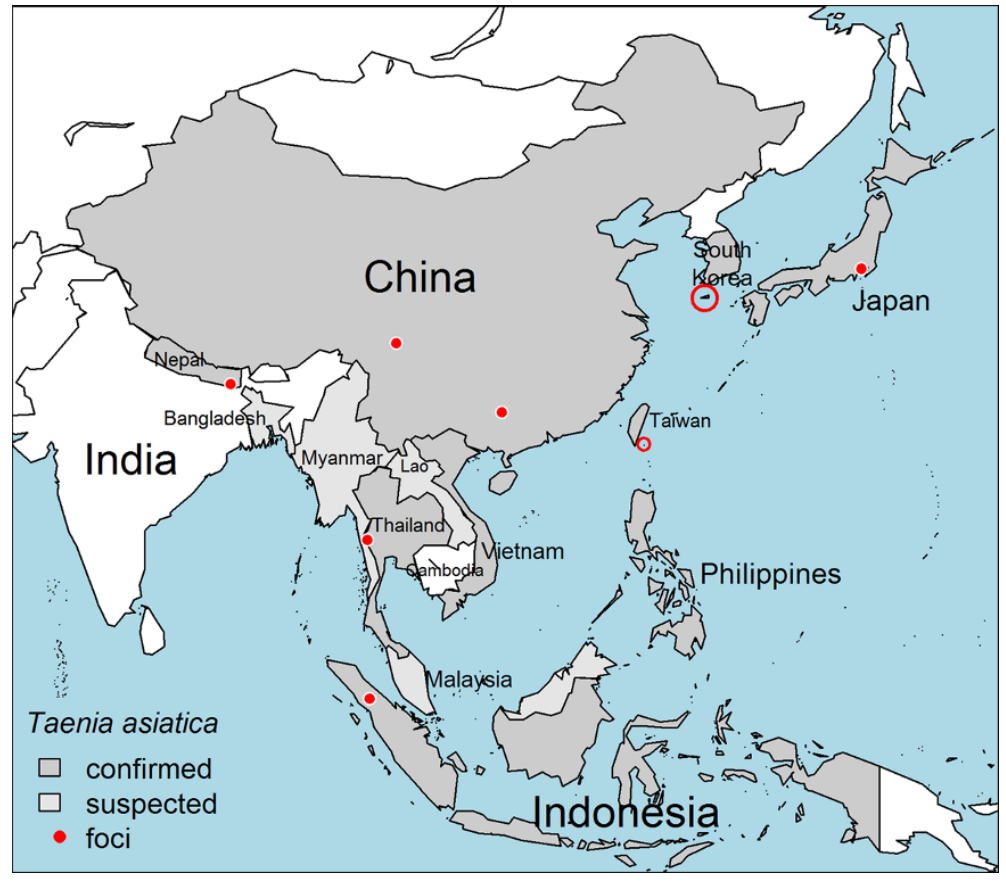

Figure 2 Country-level geographical distribution of Taenia asiatica. In China, T. asiatica has so far only been identified in the south-central provinces Yunnan, Guangxi, Guizhou and Sichuan. The ethno-geographical foci refer to, from west to east: Morang \& Itahari district (Nepal); Thong Pha Phum district (Kanchanaburi province; Thailand); Samosir Island (North Sumatra, Indonesia); Yajiang (Nyagqu) County (Garzê Tibetan Autonomous Prefecture, Sichuan Province, China); Luzhai County (Guangxi Zhuang Autonomous Region, China); Orchid island (Lanyu Township, Taitung County, Taiwan); Jeju Island (Jeju-do, South Korea); and Kanto region (Honshu, Japan).

initially labeled as $T$. saginata. Current knowledge on taeniosis and $T$. asiatica in Taiwan and South Korea is reviewed by, respectively, [2], and [55,71].

Fan et al. identified in their original studies the presence of $T$. asiatica in Indonesia, Thailand and the Philippines based on morphological characteristics $[7,9,10]$. These findings were later confirmed by molecular characterization of individual specimens originating from these countries. $T$. asiatica has so far mainly been identified on Sumatra [29,72]. During 2003-2005, an epidemiological survey on 240 local people identified six T. asiatica tapeworm carriers (2.5\%), using mitochondrial DNA analysis [53,54]. The presence of $T$. asiatica on Bali, on the other hand, remains controversial. No human $T$. asiatica taeniosis cases have been confirmed [54,73,74], but in 1998, 146 of 638 pigs (22.9\%) at a slaughter-house in Bali were found to have cysts in the liver [31], and more recently, one cyst originating from Bali was identified as $T$. asiatica by multiplex Polymerase Chain Reaction (PCR) [67]. The current knowledge on taeniosis and cysticercosis in Indonesia has recently also been reviewed by Wandra et al. [75]. In Thailand, different $T$. asiatica cases, including one triple infection and one co-infection with $T$. solium, have been identified in the Myanmar-bordering Kanchanaburi province $[29,60,61]$. The current status of taeniasis in Thailand is further reviewed by Anantaphruti [62]. In the Philippines, finally, different authors identified individual $T$. asiatica specimens $[29,68,69]$, but no epidemiological studies appear to have been performed.

McManus \& Bowles [15] report the first confirmation of T. asiatica from mainland China, but without providing details on the exact origin of the examined specimen. Further research identified T. asiatica cases in four southcentral provinces of China, i.e., Yunnan, Guangxi, Guizhou and Sichuan. Zhang et al. [36] were the first to identify $T$. asiatica in Yunnan province, based on morphological characteristics of adults and cysts. To date, specimens have been molecularly confirmed from three Yunnan counties, i. e., Lanpin, Dali and Baoshan [20,76-78]. Eom et al. [57] identified six cases from the Zhuang minority in Guangxi province. Other specimens have been confirmed from Luzhai and Binyang county in Guangxi [68,79]. Furthermore, cases have been confirmed from Duyun and Congjiang county in Guizhou province [20,76,80,81], and from Yajiang and Danba county in Sichuan province $[30,58,82]$.

More recently, it has become clear that the geographical distribution of $T$. asiatica is more widespread than originally thought, as cases have been confirmed in Vietnam, Japan and Nepal. In 2003, a case report was published on a patient from Ha Tay province, Vietnam, suffering from taeniosis [83]. DNA analysis revealed that 
the causative species was T. asiatica. Somers et al. [84] confirmed 36 out of 65 human tapeworm cases in North Vietnam as T. asiatica. In 2010, the Infectious Agents Surveillance Report of the Japanese National Institute of Infectious Diseases dedicated a section to the detection of several $T$. asiatica cases in Kanto region (reviewed by $[64,85])$. These were the first and so far only case reports from Japan, although two museum samples had earlier been molecularly characterized as $T$. asiatica $[51,72]$. In Nepal, several $T$. asiatica tapeworm carriers were identified among the Dum, an indigenous community living along the Nepal-India border [65]. So far, this is the most western location where $T$. asiatica has been found.

For other South-Asian and South-East-Asian countries, i.e., Bangladesh, Myanmar, Malaysia, Lao PDR, and Cambodia, there is considerable uncertainty regarding the presence of $T$. asiatica. Amin et al. [86] reported a case of a symptomatic tapeworm carrier from rural Bangladesh. As the patient reportedly had not consumed undercooked beef, but possibly undercooked pork, the case was ascribed to T. asiatica. Nevertheless, as no morphological or molecular identification was performed, this diagnosis remains questionable. No cases have been confirmed from Myanmar, but Anantaphruti [62] identified T. asiatica in a Karen immigrant who recently moved from Myanmar to Kanchanaburi province, Thailand, and was passing segments in stool before migration. McManus \& Bowles [15] identified one specimen from Malaysia as T. asiatica, and Conlan et al. [74] mentioned the finding of $T$. asiatica in one of 590 pig livers sampled in Lao PDR, but further evidence for these countries remains lacking. In Cambodia, finally, the only identification study conducted so far could not identify $T$. asiatica among 21 tapeworm carriers [87].

\section{Genetic diversity}

Since the 1990s, various researchers have developed and applied molecular methods for distinguishing $T$. asiatica from other Taenia spp., and, subsequently, for studying the relationship of $T$. asiatica with other Taenia spp., in particular T. saginata, and for examining the genetic variability within $T$. asiatica. The availability of the complete mitochondrial genome of $T$. asiatica [27], and the access to published sequences through GenBank, has greatly contributed to the understanding of the genetic diversity of T. asiatica.

\section{Molecular tools for Taenia asiatica identification}

Different tools have been developed to differentiate $T$. asiatica from other Taenia species based on the genetic information available in proglottids, cysts and eggs. Table 2 gives an overview of the different molecular tools and markers developed so far. To date, the most common method for molecular identification of Taenia tapeworms has been PCR coupled with nucleotide sequencing of the amplified PCR product. Different mitochondrial (e.g., cytochrome c oxidase subunit I [COX-1], cytochrome b $[C O B], \mathrm{NADH}$ dehydrogenase subunit I [NAD-1], and $12 \mathrm{~s}$ ribosomal RNA) and nuclear (e.g., ribosomal RNA (i.e., 18S rRNA, 5.8S rRNA, internal transcribed spacer 2 [ITS-2], and 28S rRNA), elongation factor-1-alpha [ef1], and ezrin/radixin/moesin-like protein $[e l p])$ genes have been used as markers in such analyses (Table 2). By aligning the obtained sequences with published ones, the identity of the specimens can be determined [21]. Other assays for the differential diagnosis of Taenia tapeworms include PCR $[13,69,93]$, PCR coupled with Restriction Fragment Length Polymorphism analysis (PCR-RFLP; [13,15,84,93,94]), Random Amplified Polymorphic DNA analysis (RAPD; [20,57]), Base Excision Sequence Scanning Thymine-base analysis (BESS T-base; [66]), multiplex PCR $[67,68,93]$, and Loop-Mediated Isothermal Amplification (LAMP; [28]).

\section{Genetic relatedness of Taenia asiatica, Taenia saginata and Taenia solium}

With the availability of the mitochondrial genome of the different human taeniids, their genetic relatedness has become clearer [25-27]. The mitochondrial genomes of $T$. asiatica, T. saginata and T. solium measure 13,703 bp, $13,670 \mathrm{bp}$, and 13,709 bp, respectively. They consist of 36 genes, i.e., 12 protein-coding genes, 22 tRNA genes, and 2 rRNA genes. There is an overall nucleotide difference of $4.6 \%$ between $T$. asiatica and $T$. saginata, and of $11 \%$ between $T$. saginata and T. solium. The nucleotide difference in the COX-1 gene is $4.6 \%$ for $T$. asiatica/T. saginata, $12.3 \%$ for T. saginata/T. solium, and $12.0 \%$ for T. asiatical $T$. solium. These results thus indicate that $T$. asiatica is more closely related to $T$. saginata than it is to $T$. solium.

Similar conclusions are obtained from sequence comparisons of nuclear genes. The $18 \mathrm{kDa} / \mathrm{HP} 6$ protein-encoding gene shows a similarity of $95.5 \%$ between $T$. asiatica and $T$. saginata, but a similarity of merely $61.5 \%$ between $T$. saginata and T. solium [91]. The 18S rRNA genes of T. asiatica and T. saginata appeared to be $99.2 \%$ identical [78].

Studies on the diversification times of the different Taenia species indicate that $T$. asiatica fully diverged from a common $T$. saginata/asiatica ancestor in the late Pleistocene, $\sim 40,000$ years ago. This diversification might have co-occurred with the arrival of Homo sapiens in Asia, and the introduction of new wild boar populations and/or new breeding and husbandry practices in this region $[63,95]$. Again, these results indicate a closer relatedness of $T$. asiatica with $T$. saginata than with $T$. solium.

\section{Genetic variability within Taenia asiatica}

Several studies have indicated little or no genetic variation within $T$. asiatica. The nucleotide diversity found 
Table 2 Molecular tools for T. asiatica identification

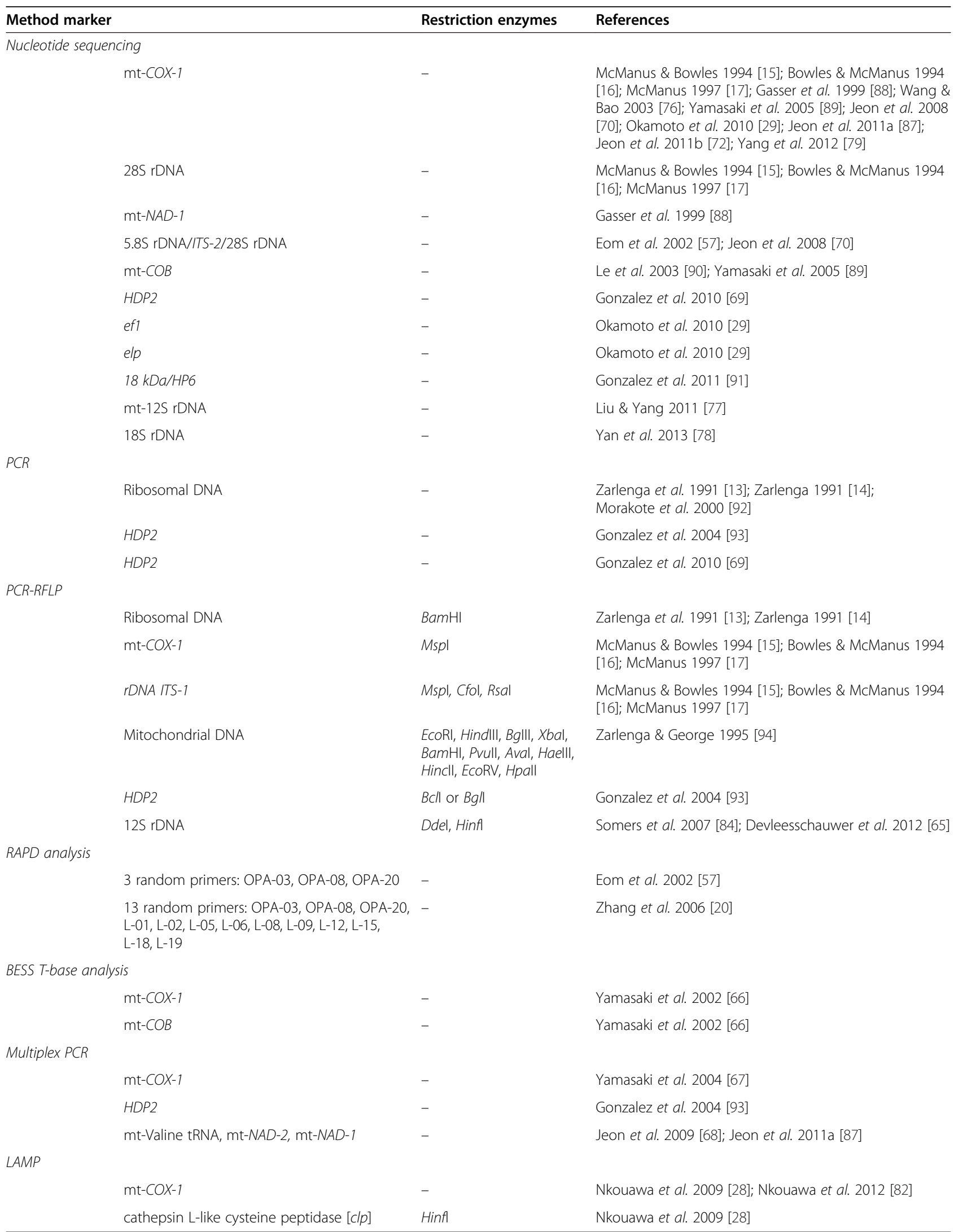


in the mitochondrial $C O X-1$ gene of specimens from different regions ranged between 0 and $0.2 \%$ [16,26,67]. $T$. saginata, on the other hand, appears to show an important genetic polymorphism, with mitochondrial $C O X-1$ gene diversity ranging from 0.2 to $0.8 \%$ [26]. In an analysis of $C O X-1$ gene sequences of $30 \mathrm{~T}$. asiatica specimens from seven countries, only two haplotypes could be identified, with the major haplotype comprising 29 out of 30 samples. T. saginata, on the other hand, was found to be much more polymorphic, with eight haplotypes and a ten times higher haplotype diversity (0.70 versus 0.07 ; $[96,97])$.

The limited amount of genetic variation within $T$. asiatica has also been observed for other genes. Indeed, sequence divergences of 0.1 to $2.1 \%$ were found in $T$. asiatica HDP2 fragments [69], while no divergence was found in the $18 \mathrm{kDa}$ gene sequence [91].

In contrast with this low genetic diversity is the recent identification of potential hybrids between $T$. asiatica and T. saginata. Nkouawa et al. [28] identified two specimens, one from China and one from Thailand, that were identified as $T$. saginata based on the mitochondrial $C O X-1$ gene, but as $T$. asiatica based on the nuclear cathepsin L-like cysteine peptidase gene. It is therefore possible that these specimens were hybrid parasites with $T$. saginata mitochondrial DNA and $T$. asiatica nuclear DNA. Likewise, a discrepancy between the mitochondrial and nuclear DNA was found in two tapeworm specimens from Thailand [29]. While the specimens had sequences typical of the T. saginata COX-1 gene, both were homozygous for T. asiatica typical alleles of the elp gene, and one was additionally homozygous for $T$. asiatica typical alleles of the ef1 gene. A similar mitochondrial/nuclear discordance was observed in China, where one tapeworm with $T$. asiatica mitochondrial DNA was heterozygous for $T$. saginata typical alleles of the elp and ef1 genes, while a second tapeworm, with $T$. saginata mitochondrial DNA, was heterozygous for T. asiatica typical alleles of the ef1 gene [30].

\section{Conclusions}

In the past 50 years, $T$. asiatica has made a remarkable journey through the scientific literature, from epidemiological paradox to mitochondrial genome. The studies performed in the 1980s and 1990s have provided us with the basic understanding of its transmission and risk factors. Nevertheless, several critical questions remain unanswered. As studies on the T. asiatica transmission risk factors so far mainly focused on pork liver consumption, other important factors, such as pig husbandry and slaughter practices, remain unaddressed. Furthermore, the potential of $T$. asiatica to cause human cysticercosis needs to be clarified. If this would be the case, then $T$. asiatica could be an important cause of cross reactions in serological assays, but, more importantly, of human illness, making this indeed the most neglected of all neglected tropical diseases [98]. Finally, more needs to be done to understand if and how $T$. asiatica can protect against $T$. solium, through density-dependent and/ or immune-mediated processes [99]. Indeed, as humans may become infected with three different Taenia species, i.e., T. asiatica, T. saginata and T. solium, the presence of one tapeworm species might physically reduce the likelihood of a second species to develop. Likewise, as pigs can become infected with three Taenia species, i.e., T. asiatica, T. solium and T. hydatigena, cross-immunity may interfere with the establishment of cysts of other species. If such interspecific competition could be proven to play an important role in moderating $T$. solium transmission, $T$. asiatica would indeed be a parasite to treasure and to save from extinction [100].

With increasing access to molecular tools, the geographical distribution of $T$. asiatica has been shown to be much more widespread than initially thought. Indeed, the recent confirmation of $T$. asiatica in Nepal shows that its distribution is not restricted to South-East-Asia, as was thought so far. Further studies are warranted to identify the true spread of this parasite.

Over the last 20 years, genetic studies have provided important insights into the past, present and future of $T$. asiatica. The limited genetic diversity of $T$. asiatica specimens may be a signal that $T$. asiatica is an endangered species [96,97]. Indeed, as its transmission is rooted in often ancient sociocultural habits, the gradual disappearance of these habits along with global development and globalization, may lead to the spontaneous extinction of $T$. asiatica. Such a scenario is certainly not unrealistic, as it happened for T. solium in Europe [101] and observations from Indonesia and South Korea indicate that with changing habits, taeniosis prevalences decrease [102]. Finally, the significance of putative hybrids needs to be clarified, and more studies are needed to ascertain whether or not hybridization between $T$. asiatica and other species still occurs today.

\section{Abbreviations}

BESS T-base: Base excision sequence scanning thymine-base; COX1: Cytochrome c oxidase subunit l; COB: Cytochrome b; ef1: Elongation factor-1-alpha; elp: ezrin/radixin/moesin-like protein; ITS-2: Internal transcribed spacer 2; LAMP: Loop-mediated isothermal amplification; NAD-1: NADH dehydrogenase subunit l; PCR: Polymerase chain reaction; RAPD: Random amplified polymorphic DNA; RFLP: Restriction fragment length polymorphism; rRNA: ribosomal ribonucleic acid.

\section{Competing interests}

The authors declare that they have no competing interests.

\section{Authors' contributions}

$A A$ and $B D$ performed the systematic literature review. $A A$ and $B D$ conceived and wrote the review with assistance from BV, NP, SG, NS, and PD. All authors read and approved the final manuscript. 


\section{Acknowledgement}

The authors would like to thank the two anonymous reviewers for their valuable comments. BD is supported by the Special Research Fund (BOF) of Ghent University.

\section{Author details}

${ }^{1}$ National Zoonoses and Food Hygiene Research Center, Kathmandu, Nepal. ${ }^{2}$ Department of Biomedical Sciences, Institute of Tropical Medicine, Antwerp, Belgium. ${ }^{3}$ Institute of Health and Society (IRSS), Université catholique de Louvain, Brussels, Belgium. ${ }^{4}$ Department of Virology, Parasitology and Immunology, Faculty of Veterinary Medicine, Ghent University, Merelbeke, Belgium.

Received: 15 October 2013 Accepted: 8 January 2014

Published: 22 January 2014

\section{References}

1. Fan PC: Taiwan Taenia and taeniasis. Parasitol Today 1988, 4:86-88.

2. Ooi HK, Ho CM, Chung WC: Historical overview of Taenia asiatica in Taiwan. Korean J Parasitol 2013, 51:31-36.

3. Rhoads ML, Murrell KD, Cross JH, Fan PC: The serological response of pigs experimentally infected with a species of Taenia from Taiwan. Vet Parasitol 1989, 30:279-285.

4. Fan PC: Asian Taenia saginata: species or strain? Southeast Asian J Trop Med Public Health 1991, 22(Suppl):245-250.

5. Fan PC: Review of taeniasis in Asia. Zhonghua Min Guo Wei Sheng Wu Ji Mian Yi Xue Za Zhi 1995, 28:79-94.

6. Fan PC, Chung WC: Taenia saginata asiatica: epidemiology, infection, immunological and molecular studies. J Microbiol Immunol Infect 1998, 31:84-89.

7. Fan PC, Lin CY, Kosman ML, Kosin E: Experimental infection of Indonesia Taenia (Samosir strain) in domestic animals. Int J Parasitol 1989, 19:809-812.

8. Fan PC, Lin CY, Wu CC, Chung WC, Soh CT: Experimental studies of Korea Taenia (Cheju strain) infection in domestic animals. Ann Trop Med Parasitol 1989, 83:395-403.

9. Fan PC, Chung WC, Lin CY, Wu CC: Experimental infection of Thailand Taenia (Chiengmai strain) in domestic animals. Int J Parasitol 1990, 20:121-123.

10. Fan PC, Lin CY, Chung WC: Experimental infection of Philippine Taenia in domestic animals. Int J Parasitol 1992, 22:235-238.

11. Eom KS, Rim HJ, Geerts S: Experimental infection of pigs and cattle with eggs of Asian Taenia saginata with special reference to its extrahepatic viscerotropism. Kisaengchunghak Chapchi 1992, 30:269-275.

12. Eom KS, Rim HJ: Morphologic descriptions of Taenia asiatica sp. n. Korean J Parasitol 1993, 31:1-6.

13. Zarlenga DS, McManus DP, Fan PC, Cross $\mathrm{JH}$ : Characterization and detection of a newly described Asian taeniid using cloned ribosomal DNA fragments and sequence amplification by the polymerase chain reaction. Exp Parasitol 1991, 72:174-183.

14. Zarlenga DS: The differentiation of a newly described Asian taeniid from Taenia saginata using enzymatically amplified non-transcribed ribosomal DNA repeat sequences. Southeast Asian J Trop Med Public Health 1991, 22(Suppl):251-255.

15. McManus DP, Bowles J: Asian (Taiwan) Taenia: species or strain? Parasitol Today 1994, 10:273-275.

16. Bowles J, McManus DP: Genetic characterization of the Asian Taenia, a newly described taeniid cestode of humans. Am J Trop Med Hyg 1994, 50:33-44.

17. McManus DP: Molecular genetic variation in Echinococcus and Taenia: an update. Southeast Asian J Trop Med Public Health 1997, 28(Suppl 1):110-116.

18. Fan PC, Lin CY, Chen CC, Chung WC: Morphological description of Taenia saginata asiatica (Cyclophyllidea: Taeniidae) from man in Asia. J Helminthol 1995, 69:299-303.

19. Galan-Puchades MT, Mas-Coma S: Considering Taenia asiatica at species level. Parasitol Today 1996, 12:123. author reply 123.

20. Zhang $\mathrm{K}$, Yang M, Bao HE: The random amplified polymorphic DNA identification of 9 Taenia saginata isolates from four provinces. Zhongguo $\mathrm{Ji}$ Sheng Chong Xue Yu Ji Sheng Chong Bing Za Zhi 2006, 24:420-424.

21. McManus DP: Molecular discrimination of taeniid cestodes. Parasitol Int 2006, 55(Suppl):S31-37.

22. De Queiroz A, Alkire NL: The phylogenetic placement of Taenia cestodes that parasitize humans. J Parasitol 1998, 84:379

23. Hoberg EP, Jones A, Rausch RL, Eom KS, Gardner SL: A phylogenetic hypothesis for species of the genus Taenia (Eucestoda: Taeniidae). J Parasitol 2000, 86:89-98.
24. Hoberg EP: Phylogeny of Taenia: Species definitions and origins of human parasites. Parasitol Int 2006, 55(Suppl):S23-30.

25. Jeon HK, Kim KH, Eom KS: Complete sequence of the mitochondrial genome of Taenia saginata: comparison with $T$. solium and T. asiatica. Parasitol Int 2007, 56:243-246.

26. Jeon HK, Eom KS: Taenia asiatica and Taenia saginata: genetic divergence estimated from their mitochondrial genomes. Exp Parasitol 2006, 113:58-61.

27. Jeon HK, Lee KH, Kim KH, Hwang UW, Eom KS: Complete sequence and structure of the mitochondrial genome of the human tapeworm, Taenia asiatica (Platyhelminthes; Cestoda). Parasitology 2005, 130:717-726.

28. Nkouawa A, Sako Y, Nakao M, Nakaya K, Ito A: Loop-mediated isothermal amplification method for differentiation and rapid detection of Taenia species. J Clin Microbiol 2009, 47:168-174.

29. Okamoto M, Nakao M, Blair D, Anantaphruti MT, Waikagul J, Ito A: Evidence of hybridization between Taenia saginata and Taenia asiatica. Parasitol Int 2010, 59:70-74

30. Yamane K, Suzuki Y, Tachi E, Li T, Chen X, Nakao M, Nkouawa A, Yanagida T, Sako $Y$, Ito A, et al: Recent hybridization between Taenia asiatica and Taenia saginata. Parasitol Int 2012, 61:351-355.

31. Simanjuntak G, Margono S, Okamoto M, Ito A: Taeniasis/cysticercosis in Indonesia as an emerging disease. Parasitol Today 1997, 13:321-323.

32. Eom KS: What is Asian Taenia? Parasitol Int 2006, 55(Suppl):S137-141.

33. Eom KS, Rim HJ: Experimental human infection with Asian Taenia saginata metacestodes obtained from naturally infected Korean domestic pigs. Kisaengchunghak Chapchi 1992, 30:21-24.

34. Chung WC, Lin CY, Fan PC: Ectopic locations of Taenia saginata asiatica cysticerci in the abdominal cavity of domestic pig and monkey. J Parasitol 1996, 82:1032-1034.

35. Fall EH, Geerts S, Kumar V, Vervoort T, De Deken R, Eom KS: Failure of experimental infection of baboons (Papio hamadryas) with the eggs of Asian Taenia. J Helminthol 1995, 69:367-368.

36. Zhang L, Tao H, Zhang B, Wang H, Wang Y, Li Z, Yang J, Yang B, Li Y, Pang $Y$, et al: First discovery of Taenia saginata asiatica infection in Yunnan province. Zhongguo Ji Sheng Chong Xue Yu Ji Sheng Chong Bing Za Zhi 1999, 17:95-96.

37. Chao D, Wong MM, Fan PC: Experimental infection in a human subject by a possibly undescribed species of Taenia in Taiwan. J Helminthol 1988, 62:235-242

38. Chang SL, Ooi HK, Nonaka N, Kamiya M, Oku Y: Development of Taenia asiatica cysticerci to infective stage and adult stage in Mongolian gerbils. J Helminthol 2006, 80:219-223.

39. Chung WC, Fan PC, Lin CY, Wu CC: Studies of taeniasis in Taiwan. XII. Prevalence of taeniasis among Atayal aborigines in Wufeng District, Hsinchu County, northwest Taiwan. Gaoxiong Yi Xue Ke Xue Za Zhi 1990, 6:66-72.

40. Fan $\mathrm{PC}$, Chung WC, Lin $\mathrm{CY}$, Chan $\mathrm{CH}$ : Clinical manifestations of taeniasis in Taiwan aborigines. J Helminthol 1992, 66:118-123.

41. Galan-Puchades MT, Fuentes MV: The Asian Taenia and the possibility of cysticercosis. Korean J Parasitol 2000, 38:1-7.

42. Galan-Puchades MT, Fuentes MV: Taenia asiatica intermediate hosts. Lancet 2004, 363:660.

43. Ito A: Basic and applied immunology in cestode infections: from Hymenolepis to Taenia and Echinococcus. Int J Parasitol 1997, 27:1203-1211.

44. Ito A, Fan PC, Chung WC, Suzuki M: Cross protection against Taenia taeniaeformis in rats vaccinated with non-viable oncospheres of Asian Taenia or T. saginata. J Helminthol 1994, 68:83-85.

45. Fan PC, Chung WC, Eom KS, Ito A: Vaccination trials against Taiwan Taenia eggs in pigs injected with frozen oncospheres of Taiwan Taenia, Korea Taenia, T. saginata or T. solium. Parasitology 1997, 114(Pt 6):541-544.

46. Fan PC, Chung WC, Lin CY, Wu CC: Vaccination trials against Taenia solium eggs in pigs injected with frozen oncospheres of $T$. solium or Taenia saginata asiatica. J Microbiol Immunol Infect 2003, 36:96-100.

47. Jeon HK, Eom KS: Immunoblot patterns of Taenia asiatica taeniasis. Korean J Parasitol 2009, 47:73-77.

48. Lee EG, Bae YA, Kim SH, Diaz-Camacho SP, Nawa Y, Kong Y: Serodiagnostic reliability of single-step enriched low-molecular weight proteins of Taenia solium metacestode of American and Asian isolates. Trans $R$ SoC Trop Med Hyg 2010, 104:676-683.

49. Fan PC, Chung WC, Lin CY, Wu CC: Prevalence of taeniasis and enterobiasis among aboriginal children in mountainous areas of Taiwan. Gaoxiong Yi Xue Ke Xue Za Zhi 1990, 6:475-482. 
50. Fan PC, Chung WC, Lin CY, Wu CC: Studies of taeniasis in Taiwan. XIV. Current status of taeniasis among Yami aborigines on Lanyu Island, Taitung County, southeast Taiwan. Gaoxiong Yi Xue Ke Xue Za Zhi 1992 8:266-271.

51. Eom KS, Jeon HK, Rim HJ: Geographical distribution of Taenia asiatica and related species. Korean J Parasitol 2009, 47(Suppl):S115-124.

52. Fan PC, Chung WC, Soh CT, Kosman ML: Eating habits of east Asian people and transmission of taeniasis. Acta Trop 1992, 50:305-315.

53. Suroso T, Margono SS, Wandra T, Ito A: Challenges for control of taeniasis/ cysticercosis in Indonesia. Parasitol Int 2006, 55(Suppl):S161-165.

54. Wandra T, Depary AA, Sutisna P, Margono SS, Suroso T, Okamoto M, Craig PS, Ito A: Taeniasis and cysticercosis in Bali and North Sumatra, Indonesia. Parasitol Int 2006, 55(Suppl):S155-160.

55. Eom KS, Rim HJ: Epidemiological understanding of Taenia tapeworm infections with special reference to Taenia asiatica in Korea. Korean $J$ Parasitol 2001, 39:267-283.

56. Galan-Puchades MT, Fuentes MV: Neurcysticercosis, Taenia asiatica and Cheju Island in Korea. Trends Parasitol 2001, 17:469-470.

57. Eom KS, Jeon HK, Kong Y, Hwang UW, Yang Y, Li X, Xu L, Feng Z, Pawlowski ZS, Rim HJ: Identification of Taenia asiatica in China: molecular, morphological, and epidemiological analysis of a Luzhai isolate. J Parasitol 2002, 88:758-764.

58. Li T, Craig PS, Ito A, Chen X, Qiu D, Qiu J, Sato MO, Wandra T, Bradshaw H, Li L, et al: Taeniasis/cysticercosis in a Tibetan population in Sichuan Province, China. Acta Trop 2006, 100:223-231.

59. Li T, Chen X, Yanagida T, Wang H, Long C, Sako Y, Okamoto M, Wu Y, Giraudoux P, Raoul F, et al: Detection of human taeniases in Tibetan endemic areas, China. Parasitology 2013, 140:1602-1607.

60. Anantaphruti MT, Yamasaki H, Nakao M, Waikagul J, Watthanakulpanich D, Nuamtanong S, Maipanich W, Pubampen S, Sanguankiat S, Muennoo C, et al: Sympatric occurrence of Taenia solium, T. saginata, and T. asiatica, Thailand. Emerg Infect Dis 2007, 13:1413-1416.

61. Anantaphruti MT, Okamoto M, Yoonuan T, Saguankiat S, Kusolsuk T, Sato M, Sato MO, Sako Y, Waikagul J, Ito A: Molecular and serological survey on taeniasis and cysticercosis in Kanchanaburi Province, Thailand. Parasitol Int 2010, 59:326-330.

62. Anantaphruti MT: Current status of taeniasis in Thailand. Korean J Parasitol 2013, 51:37-42.

63. Michelet $L$, Dauga $C$ : Molecular evidence of host influences on the evolution and spread of human tapeworms. Biol Rev Camb Philos Soc 2012, 87:731-741.

64. Yamasaki $\mathrm{H}$ : Current status and perspectives of cysticercosis and taeniasis in Japan. Korean J Parasitol 2013, 51:19-29.

65. Devleesschauwer B, Aryal A, Joshi DD, Rijal S, Sherchand JB, Praet N, Speybroeck N, Duchateau L, Vercruysse J, Dorny P: Epidemiology of Taenia solium in Nepal: is it influenced by the social characteristics of the population and the presence of Taenia asiatica? Trop Med Int Health 2012, 17:1019-1022.

66. Yamasaki H, Nakao M, Sako Y, Nakaya K, Sato MO, Mamuti W, Okamoto M, Ito A: DNA differential diagnosis of human taeniid cestodes by base excision sequence scanning thymine-base reader analysis with mitochondrial genes. J Clin Microbiol 2002, 40:3818-3821.

67. Yamasaki H, Allan JC, Sato MO, Nakao M, Sako Y, Nakaya K, Qiu D, Mamuti W, Craig PS, Ito A: DNA differential diagnosis of taeniasis and cysticercosis by multiplex PCR. J Clin Microbiol 2004, 42:548-553.

68. Jeon HK, Chai JY, Kong Y, Waikagul J, Insisiengmay B, Rim HJ, Eom KS: Differential diagnosis of Taenia asiatica using multiplex PCR. Exp Parasitol 2009, 121:151-156.

69. Gonzalez LM, Bailo B, Ferrer E, Garcia MD, Harrison LJ, Parkhouse MR, McManus DP, Garate T: Characterization of the Taenia spp HDP2 sequence and development of a novel PCR-based assay for discrimination of Taenia saginata from Taenia asiatica. Parasit Vectors 2010, 3:51.

70. Jeon HK, Kim KH, Chai JY, Yang HJ, Rim HJ, Eom KS: Sympatric distribution of three human Taenia tapeworms collected between 1935 and 2005 in Korea. Korean J Parasitol 2008, 46:235-241.

71. Chai JY: Human taeniasis in the Republic of Korea: hidden or gone? Korean J Parasitol 2013, 51:9-17.

72. Jeon HK, Kim KH, Eom KS: Molecular identification of Taenia specimens after long-term preservation in formalin. Parasitol Int 2011, 60:203-205.

73. Wandra T, Sutisna P, Dharmawan NS, Margono SS, Sudewi R, Suroso T, Craig PS, Ito A: High prevalence of Taenia saginata taeniasis and status of
Taenia solium cysticercosis in Bali, Indonesia, 2002-2004. Trans R Soc Trop Med Hyg 2006, 100:346-353.

74. Conlan JV, Sripa B, Attwood S, Newton PN: A review of parasitic zoonoses in a changing Southeast Asia. Vet Parasitol 2011, 182:22-40.

75. Wandra T, Ito A, Swastika K, Dharmawan NS, Sako Y, Okamoto M: Taeniases and cysticercosis in Indonesia: past and present situations. Parasitology 2013, 140:1608-1616.

76. Wang ZR, Bao HE: Identification of Taenia saginata by $\mathrm{mtCO} I$ in fou areas of Yunnan and Guizhou provinces. Zhongguo Ji Sheng Chong Xue Yu Ji Sheng Chong Bing Za Zhi 2003, 21:20-23.

77. Liu AB, Yang YM: Analysis of the mitochondrial DNA-gene encoding ribosomal RNA small subunit gene sequence of Taenia cestode from Baoshan and Puer areas in Yunnan Province. Chinese Journal of Infectious Diseases 2011, 29:236-238.

78. Yan H, Lou Z, Li L, Ni X, Guo A, Li H, Zheng Y, Dyachenko V, Jia W: The nuclear $18 \mathrm{~S}$ ribosomal RNA gene as a source of phylogenetic information in the genus Taenia. Parasitol Res 2013, 112:1343-1347.

79. Yang YC, Ou-Yang Y, Su AR, Wan XL, Li SL: Analysis of COX1 sequences of Taenia isolates from four areas of Guangxi. Zhongguo Xue Xi Chong Bing Fang Zhi Za Zhi 2012, 24:307-310

80. Chen Y, Bao HE, Li JF, Lang SY, Qiu XL, Huang J, Wu YM, Zhang CY Epidemiological investigation of Taenia saginata asiatica in Duyun, Guizhou and detection of amino acids and elements of adult worms. Zhongguo Ji Sheng Chong Xue Yu Ji Sheng Chong Bing Za Zhi 2003, 21:311-313.

81. Mou R, Bao HE, Qiu XL, Chen Y, Lang SY, Huang J, Li JH, Zhu WJ, Zhang K, Ling-Hu Y: Morphological observation on the adult worms of Taenia saginata in western China. Zhongguo Ji Sheng Chong Xue Yu Ji Sheng Chong Bing Za Zhi 2007, 25:32-35.

82. Nkouawa A, Sako Y, Li T, Chen X, Nakao M, Yanagida T, Okamoto M, Giraudoux P, Raoul F, Nakaya K, et al: A loop-mediated isothermal amplification method for a differential identification of Taenia tapeworms from human: application to a field survey. Parasitol Int 2012, 61:723-725.

83. Van De N: Molecular identification of Taenia asiatica isolated from a patient in Ha Tay province of Vietnam. Journal of Medical and Pharmaceutical Information 2003, 10:28-32.

84. Somers R, Dorny P, Geysen D, Nguyen LA, Thach DC, Vercruysse J, Nguyen VK: Human tapeworms in north Vietnam. Trans R Soc Trop Med Hyg 2007, 101:275-277.

85. Ohnishi K, Sakamoto N, Kobayashi K, Iwabuchi S, Nakamura-Uchiyama F: Therapeutic effect of praziquantel against taeniasis asiatica. Int J Infect Dis 2013, 17:e656-657.

86. Amin MR, Rabbi SF, Zaman MF, Rahman MK: Pork tapeworm (Taenia saginata asiatica) infection in rural Bangladesh. J Med 2009, 10:135-138.

87. Jeon HK, Yong TS, Sohn WM, Chai JY, Hong SJ, Han ET, Jeong HG, Chhakda $\mathrm{T}$, Sinuon M, Socheat D, Eom KS: Molecular identification of Taenia tapeworms by Cox1 gene in Koh Kong, Cambodia. Korean J Parasitol 2011, 49:195-197.

88. Gasser RB, Zhu X, McManus DP: NADH dehydrogenase subunit 1 and cytochrome $\mathrm{c}$ oxidase subunit I sequences compared for members of the genus Taenia (Cestoda). Int J Parasitol 1999, 29:1965-1970.

89. Yamasaki H, Nakao M, Sako Y, Nakaya K, Ito A: Molecular identification of Taenia solium cysticercus genotype in the histopathological specimens. Southeast Asian J Trop Med Public Health 2005, 36(Suppl 4):131-134.

90. Le T, De N, Doanh N, Nga N: Molecular identification and phylogenetic analysis of human parasitic Taenia sp isolated in Vietnam. Journal of Malaria and Parasite Diseases Control 2003, 0:65-73.

91. Gonzalez LM, Ramiro R, Garcia L, Parkhouse RM, McManus DP, Garate T: Genetic variability of the $18 \mathrm{kDa} / \mathrm{HP} 6$ protective antigen in Taenia saginata and Taenia asiatica: implications for vaccine development. Mol Biochem Parasitol 2011, 176:131-134.

92. Morakote N, Wijit A, Uparanukraw P: Further search for Taenia saginata asiatica in Chiang Mai, Thailand. Ann Trop Med Parasitol 2000, 94:521-524.

93. Gonzalez LM, Montero E, Morakote N, Puente S: Diaz De Tuesta JL, Serra T, Lopez-Velez R, McManus DP, Harrison LJ, Parkhouse RM, Garate T: Differential diagnosis of Taenia saginata and Taenia saginata asiatica taeniasis through PCR. Diagn Microbiol Infect Dis 2004, 49:183-188.

94. Zarlenga DS, George M: Taenia crassiceps: cloning and mapping of mitochondrial DNA and its application to the phenetic analysis of a new species of Taenia from Southeast Asia. Exp Parasitol 1995, 81:604-607.

95. Michelet L, Carod JF, Rakontondrazaka M, Ma L, Gay F, Dauga C: The pig tapeworm Taenia solium, the cause of cysticercosis: Biogeographic 
(temporal and spacial) origins in Madagascar. Mol Phylogenet Evol 2010, 55:744-750.

96. Anantaphruti MT, Thaenkham U, Watthanakulpanich D, Phuphisut O, Maipanich W, Yoonuan T, Nuamtanong S, Pubampen S, Sanguankiat S: Genetic diversity of Taenia asiatica from Thailand and other geographical locations as revealed by cytochrome $\mathrm{c}$ oxidase subunit 1 sequences. Korean J Parasitol 2013, 51:55-59.

97. Anantaphruti M, Thaenkham U, Kusolsuk T, Maipanich W, Saguankiat S, Pubampen S, Phuphisut O: Genetic variation and population genetics of Taenia saginata in North and Northeast Thailand in relation to Taenia asiatica. J Parasitol Res 2013, 2013:310605.

98. Galan-Puchades MT, Fuentes MV: Taenia asiatica: the most neglected human Taenia and the possibility of cysticercosis. Korean J Parasitol 2013, 51:51-54.

99. Conlan JV, Vongxay K, Fenwick S, Blacksell SD, Thompson RC: Does interspecific competition have a moderating effect on Taenia solium transmission dynamics in Southeast Asia? Trends Parasitol 2009, 25:398-403.

100. Flisser A: State of the art of Taenia solium as compared to Taenia asiatica. Korean J Parasitol 2013, 51:43-49.

101. Dorny P, Praet N: Taenia saginata in Europe. Vet Parasitol 2007, 149:22-24.

102. Ito A, Nakao M, Wandra T, Suroso T, Okamoto M, Yamasaki H, Sako Y, Nakaya K: Taeniasis and cysticercosis in Asia and the Pacific: present state of knowledge and perspectives. Southeast Asian J Trop Med Public Health 2005, 36(Suppl 4):123-130.

doi:10.1186/1756-3305-7-45

Cite this article as: Ale et al:: Epidemiology and genetic diversity of Taenia asiatica: a systematic review. Parasites \& Vectors 2014 7:45.

\section{Submit your next manuscript to BioMed Central and take full advantage of:}

- Convenient online submission

- Thorough peer review

- No space constraints or color figure charges

- Immediate publication on acceptance

- Inclusion in PubMed, CAS, Scopus and Google Scholar

- Research which is freely available for redistribution 